\title{
Coagglutination reactions between Candida albicans and oral bacteria
}

\author{
J. BAGG and R. W. SILVERWOOD
}

Department of Oral Medicine and Oral Pathology, Dental School, University of Wales College of Medicine, Heath Park, Cardiff CF4 4XY

Summary. An agglutination assay for detecting intermicrobial adherence between the cells of Candida albicans and various oral bacteria is described. Strains of Streptococcus sanguis, S. salivarius, S. mutans, S. mitis, Fusobacterium nucleatum and Actinomyces viscosus all coagglutinated with $C$. albicans. No interaction could be demonstrated between the cells of Bacteroides melaninogenicus and those of $C$. albicans. Preliminary investigations of these interactions suggest that binding of $F$. nucleatum and A. viscosus to $C$. albicans is mediated by bacterial proteins, possibly lectins. Other mechanisms must account for the binding of oral streptococci to $C$. albicans. The possible implications of these findings in relation to oral mucosal colonisation and oral candidal clearance are discussed.

\section{Introduction}

It is apparent that the initial adherence of microorganisms to mucosal surfaces is an important first step in the pathogenesis of many infections (Ofek and Beachey, 1980). Prevention of adherence could prevent infection, but the mode of attachment of Candida albicans to host cells is incompletely understood. In-vitro investigations suggest a role for mannose-containing moieties on the surface of either C. albicans or epithelial cells as mediators of adherence to human epithelium (Sandin et al., 1982; Lee and King, 1983). The pre-incubation of uroepithelial and buccal epithelial cells with fimbriate strains of Escherichia coli or Klebsiella pneumoniae increased the subsequent attachment of $C$. albicans to epithelial cells, the whole process being inhibited by mannose (Centeno et al., 1983). These data suggest that certain bacteria possess ligands that bind to both candidal and epithelial cells, and mediate adherence of the yeast by a 'bridging' action. Similar intermicrobial binding is important in the formation of dental plaque (Gibbons and Nygaard, 1970).

The possible role of this type of attachment in relation to oral colonisation by $C$. albicans has received little attention. Clearly the commensal oral bacteria are very different from those in the genitourinary tract, and normally there is a total absence of mannose-sensitive fimbriate enterobacteria. This preliminary study was designed to screen oral micro-organisms for their ability to bind to cells of

Received 5 Aug. 1985; revised version accepted 2 Dec. 1985.
C. albicans and form visible aggregates (coagglutination). The approach is similar to that employed to screen bacteria for mannose-specific lectin activity by the agglutination of yeasts (Mirelman et al., 1980), a lectin being defined as a sugar binding protein of non-immune origin. If interactions between oral bacteria and $C$. albicans are demonstrated, the hypothesis that the bacteria are involved in candidal attachment merits further investigation.

\section{Materials and methods}

\section{Bacteria}

The strains of aerobic bacteria studied were Streptococcus sanguis NCTC 10558; S. salivarius NCTC 8606; $S$. mitis 3 NCTC 10712; S. mutans D282 NCTC 10832; Staphylococcus aureus NCTC 6571 and Escherichia coli NCTC 10418. All were grown on blood agar for $24 \mathrm{~h}$ at $37^{\circ} \mathrm{C}$. The anaerobic bacteria studied were Fusobacterium nucleatum NGB 15-73; Actinomyces viscosus ATCC 15987 and Bacteroides intermedius NCTC 9336; these were grown on blood agar for $48 \mathrm{~h}$ at $37^{\circ} \mathrm{C}$, in an atmosphere of $\mathrm{H}_{2} 10 \%, \mathrm{CO}_{2} 10 \%$ and $\mathrm{N}_{2} 80 \%$.

\section{Yeasts}

Candida albicans NCPF 3281 was studied in the coagglutination experiments and was grown aerobically on Sabouraud agar for $24 \mathrm{~h}$ at $38^{\circ} \mathrm{C}$. Sixty-six fresh clinical isolates of $C$. albicans were assayed exclusively for auto-agglutinating activity after culture in the same conditions. 


\section{Agglutination assay}

In the coagglutination assay, both the yeast cells and the bacteria were suspended in potassium phosphate buffer $(0.25 \mathrm{M}, p \mathrm{H} 7 \cdot 4)$. A concentration of $C$. albicans $6 \times 10^{6} \mathrm{cfu} / \mathrm{ml}$, tested with $6 \times 10^{7}$ bacteria $/ \mathrm{ml}$ yielded the most consistent results. Samples $(1.5 \mathrm{ml})$ of bacterial and yeast-cell suspensions were mixed in $7-\mathrm{ml}$ screw-capped bottles. The bottles were sealed and rotated at $33 \mathrm{rpm}$ on a tube rotator overnight at room temperature. Results were read by pipetting a small volume of each mixture on to a microscope slide and observing agglutination with the naked eye, or. when necessary, by wet mount microscopy. Negative control preparations in which $C$. albicans and the bacteria were suspended individually in buffer were always performed, and examined for autoagglutination.

\section{Heat treatment of bacteria}

Suspensions were placed in a waterbath at $85 \mathrm{C}$ for 30 min or $60 \mathrm{~min}$.

\section{Trypsin treatment}

Bacteria were treated with Type II trypsin from porcine pancreas (Sigma Chemical Co. Ltd. Fancy Road. Poole. Dorset $\mathrm{BH} 17 \mathrm{7NH})$. The trypsin was dissolved in Tris$\mathrm{HCl}$ buffer $(0.2 \mathrm{M}, p \mathrm{H} \mathrm{7.4)}$ at a concentration of 10000 BAEE units $/ \mathrm{ml}$, and the bacteria were treated with this solution for $45 \mathrm{~min}$ in a water bath at $37 \mathrm{C}$. The bacteria were washed once after trypsinisation before the agglutination assay.

\section{Sodium metaperiodate oxidation of $C$. albicans}

Cells of C. albicans were treated for 5 min with sodium metaperiodate, at concentrations of 1,5 and $10 \mathrm{mg} / \mathrm{ml}$ in $0.25 \mathrm{M}$ potassium-phosphate buffer, $\mathrm{pH} 7.4$, at room temperature. The cells were then washed in potassiumphosphate buffer before the agglutination assay.

\section{Results}

In the buffer system described, $21 \%$ of 66 fresh isolates of $C$. albicans autoagglutinated. C. albicans 3281 , in common with most test strains, did not autoagglutinate in these conditions. Of all the bacterial strains tested, only Staph. aureus and $B$. intermedius did not coagglutinate with $C$. albicans 3281 (table I).

\section{Heat treated bacteria}

The effects of heat treatment of the bacteria on subsequent coagglutination with $C$. albicans 3281 are summarised in table II. Heat treatment abolished the agglutinating activity of $E$. coli, $F$. nucleatum and $A$. viscosus, the two anaerobes being
Table 1. Coagglutination of bacteria with C. albicans 3281

\begin{tabular}{lc} 
Bacterial strain & Result \\
\hline E. coli & + \\
Staph. aureus & - \\
S. sanguis & + \\
S. salivarius & + \\
S. mitis & + \\
B. intermedius & - \\
A. tiscosus & + \\
F. nucleatum & + \\
& \\
\hline & \\
$+=$ Agglutination; & \\
$-=$ no agglutination.
\end{tabular}

Table II. Effect of heat treatment of bacteria on their subsequent coagglutination with C. albicans 3281

\begin{tabular}{|c|c|c|c|}
\hline \multirow[b]{2}{*}{ Bacterial strain } & \multicolumn{3}{|c|}{ Agglutination after heat treatment } \\
\hline & Room temperature & $85 \mathrm{C} ; 30 \mathrm{~min}$ & $85 \mathrm{C} 60 \mathrm{~min}$ \\
\hline E. coli & + & - & - \\
\hline F. nucleatum & + & \pm & - \\
\hline A. viscosus & + & \pm & - \\
\hline S. sanguis & + & + & + \\
\hline$S$ salicarius & + & ++ & $+t+$ \\
\hline S. mitis & + & +++ & +++ \\
\hline S. mutans D282 & + & +++ & $++t$ \\
\hline
\end{tabular}

Table III. Effect of trypsin treatment* of bacteria on their subsequent coagglutination with Candida albicans 3281

\begin{tabular}{lcc}
\hline & \multicolumn{1}{c}{ Agglutination of cells } \\
& & \\
Bacterial strain & non-trypsinised & trypsinised \\
\hline F. nucleatum & + & - \\
A. . iscosus & + & - \\
S. mitis & + & - \\
S. salivarius & + & - \\
S. sanguis & + & - \\
S. mutans D282 & + & \pm \\
\hline
\end{tabular}

$+=$ Agglutination; $\pm=$ weak agglutination; $-=$ no agglutination.

* See Methods. 
Table IV. Effect of periodate treatment* of $C$. albicans 3281 on subsequent coagglutination with $F$. nucleatum and $A$. viscosus

\begin{tabular}{|c|c|c|c|}
\hline \multirow[b]{2}{*}{ C. albicans preparation } & \multicolumn{2}{|c|}{ Coagglutination with } & \multirow{2}{*}{$\begin{array}{l}\text { Autoagglutination } \\
\text { of } C \text {. albicans }\end{array}$} \\
\hline & F. nucleatum & A. viscosus & \\
\hline $\begin{array}{l}\text { Untreated C. albicans } \\
\text { C. albicans treated }\end{array}$ & ++ & ++ & - \\
\hline $\begin{array}{l}\text { with } \mathrm{NaIO}_{4} 1 \mathrm{mg} / \mathrm{ml} \\
\text { C. albicans treated }\end{array}$ & ++ & ++ & + \\
\hline $\begin{array}{l}\text { with } \mathrm{NaIO}_{4} 5 \mathrm{mg} / \mathrm{ml} \\
\text { C. albicans treated }\end{array}$ & \pm & \pm & \pm \\
\hline with $\mathrm{NaIO}_{4} 10 \mathrm{mg} / \mathrm{ml}$ & \pm & \pm & \pm \\
\hline
\end{tabular}

+ or $++=$ Agglutination; $\pm=$ weak agglutination; $-=$ no agglutination.

* See Methods.

slightly less sensitive than $E$. coli. However, heating did not reduce the coagglutinating activity of the oral streptococci with C. albicans.

\section{Trypsin treatment of bacteria}

Trypsinisation of $F$.nucleatum, A. viscosus and all four strains of oral streptococci caused either complete inhibition, or a reduction, of subsequent coagglutination with $C$. albicans 3281 (table III).

\section{Periodate treatment of C. albicans 3281}

The effects of treatment of $C$. albicans 3281 with various concentrations of sodium metaperiodate on subsequent coagglutination with $F$. nucleatum and A. viscosus are shown in table IV. Treatment with

Table V. Effect of periodate treatment* of $C$. albicans 3281 on subsequent coagglutination with oral streptococci

\begin{tabular}{lcc}
\hline & \multicolumn{2}{c}{ Coagglutination with } \\
\cline { 2 - 3 } Bacterial strain & $\begin{array}{c}\text { untreated } \\
\text { C. albicans }\end{array}$ & $\begin{array}{c}\text { periodate treated } \\
\text { C. albicans }\end{array}$ \\
\hline $\begin{array}{lcc}\text { S. mitis } \\
\text { S. sanguis }\end{array}$ & + & + \\
S. mutans D282 & + & \pm \\
S. salivarius & + & + \\
Autoagglutination & + & + \\
of C. albicans & - & \pm \\
\hline
\end{tabular}

$+=$ agglutination; $\quad \pm=$ weak agglutination; $-=$ no agglutination.

* At a concentration of $\mathrm{NaIO}_{4} 10 \mathrm{mg} / \mathrm{ml}$; see Methods periodate $1 \mathrm{mg} / \mathrm{ml}$ resulted in autoagglutination of C. albicans, but at 5 and $10 \mathrm{mg} / \mathrm{ml}$ the autoagglutination was far less marked, and resulted in a greatly reduced coagglutination with these two anaerobic bacteria.

Table $\mathrm{V}$ shows that, in contrast, periodate oxidation of C. albicans 3281 had negligible effect on its coagglutination with the four strains of oral streptococci, with the possible exception of $S$. sanguis.

\section{Discussion}

This study shows that some strains of bacteria that are commonly present in the oral cavity bind to C. albicans and form visible aggregates. If the same bacteria bind to oral mucosal or hard tissue surfaces they could function as "bridges", to bind C. albicans to oral tissues.

Strains of E. coli and Staph. aureus were employed as positive and negative controls respectively. E. coli NCTC 10418 is a fimbriate strain that produces a mannose-sensitive agglutination of $C$. albicans or Saccharomyces cerevisiae (Bagg, 1982) and Staph. aureus NCTC 6571 does not coagglutinate with yeast cells (Mirelman et al., 1980). These reports are confirmed by the present study. Although not part of the normal oral flora, E. coli may occur in the mouth as part of a replacement flora during antibiotic therapy or in immunocompromised states. In these instances, mediation of candidal adherence by $E$. coli could be important as a predisposing factor in the acute intra-oral candidoses often suffered by such patients.

$B$. intermedius was the only one of the oral bacteria tested that did not coagglutinate with $C$. albicans. Attachment of $B$. asaccharolyticus to oral surfaces has been studied (Slots and Gibbons, 1978) 
and the presence of dental plaque containing $A c t i-$ nomyces spp. and other gram-positive bacteria may be essential for the subsequent attachment and colonisation by pigmented bacteroides. This exemplifies microbial 'bridging', the interactions between particular Bacteroides strains and other oral bacteria being highly specific (Kolenbrander et al., 1985). However, Bacteroides strains comprise only a small percentage of the cultivable flora in samples of supra-gingival plaque, and they are present on the dorsum of the tongue and vestibular mucosa in very small numbers if at all (Kelstrup, 1966). Thus, even if $B$. intermedius had shown positive coagglutination with $C$. albicans, co-operation of this organism in oral mucosal colonisation by the yeast in vico would have been unlikely.

Both $A$. viscosus and F. nucleatum coagglutinated with $C$. albicans. These species of bacteria possess lectins that recognise galactose-like residues (Mongiello and Falkler, 1979; Ellen et al., 1980), and this mechanism may explain their agglutination with $C$. albicans, although sugar inhibition tests were inconclusive.

The bacteria which seem most likely to act as mediators of candidal adherence to oral mucosa are the oral streptococci. Different strains of oral streptococci bind preferentially to particular oral sites, and this correlates with their natural distribution in the mouth (Gibbons and van Houte, 1971). Gibbons and van Houte (1971) report that $S$. salivarius and $S$. sanguis were recovered in high proportions from cheek and tongue surfaces and, because these sites are often colonised by $C$. albicans, the oral streptococci appear to be ideally placed to act as "bridges" for candidal attachment.

Having shown that certain oral bacteria coagglutinate with $C$. albicans, physical and chemical treatments of both the bacteria and the yeast were performed in a preliminary study of the mechanisms involved. Agglutination of yeast cells by $E$. coli is mediated via bacterial protein (Eshdat et al., 1978) and the coagglutinating activity of this organism was reduced by heat treatment. Heat treatment of $F$. nucleatum and $A$. viscosus also abolished coagglutination with $C$. albicans, consistent with binding by bacterial protein. Heat treatment of the oral streptococci did not reduce their coagglutinating activity, a finding which is incompatible with a proteinaceous adhesin.

Trypsin treatment of $A$. viscosus and $F$. nucleatum abolished coagglutination with $C$. albicans, and suggested the involvement of bacterial protein. The oral streptococcal coagglutination with $C$. albicans was also either abolished or greatly reduced by trypsinisation of the bacteria. Adherence to epithelial cells by $S$. salivarius and $S$. mitis is also trypsin- sensitive (Gibbons et al., 1972; Liljemark and Gibbons, 1972) and electronmicroscopy has shown that a trypsin-sensitive, fibrillar 'fuzzy coat' layer on the surface of oral streptococci is responsible for their adherence (Gibbons et al., 1972). Thus the effect of trypsin in reducing coagglutination of oral streptococci with $C$. albicans may be mediated by a non-specific removal of this surface 'fuzzy coat'.

Since bacterial proteins appeared to be involved in coagglutination with $C$. albicans, a possible role for bacterial lectins was evident. Sodium metaperiodate oxidation cleaves the $\mathrm{C}-\mathrm{C}$ bond between vicinal hydroxyl groups of sugars, and disrupts carbohydrate receptors. Oxidation of $C$. albicans 3281 with sodium metaperiodate at a concentration of $1 \mathrm{mg} / \mathrm{ml}$ produced strong autoagglutination whereas with $5 \mathrm{mg} / \mathrm{ml}$ and $10 \mathrm{mg} / \mathrm{ml}$ autoagglutination was much reduced. Periodate oxidation of $C$. albicans greatly reduced subsequent coagglutination with $F$. nucleatum and $A$. viscosus. This result suggests that carbohydrate residues on the yeastcell surface may act as receptors for bacterial adhesins associated with these two organisms.

In contrast, the effect of periodate oxidation of $C$. albicans on subsequent coagglutination with oral streptococci was negligible and suggests a binding that is unlikely to involve carbohydrate receptors on the yeast-cell wall.

Clearly, binding between some oral bacteria and C. albicans occurs in vitro. The significance of this in vivo in relation to candidal attachment to the oral mucosa has not been assessed, but 'bacterial bridging' may have a role to play. The occurrence of acute intra-oral candidosis after broad-spectrum antibiotic therapy militates against a bacterial involvement in candidal attachment. However, $C$. albicans persists in the oral cavity in the presence of a normal oral flora and in this situation 'bacterial bridging' may be important in the normal carriage of $C$. albicans.

Finally, Liljemark et al (1981) showed that adherence to hydroxyapatite by large aggregates of oral streptococci was reduced compared with that of individual cells or small aggregates. Similarly, large salivary aggregates of bacteria and yeast cells may be more readily cleared from the oral cavity than are individual cells, the coagglutination described therefore acting as a non-specific host defence mechanism. In-vivo studies will clearly be necessary to fully elucidate the true biological significance of the in-vitro findings reported in this paper.

We thank Dr D. M. Walker for encouragement during the investigation, and Mrs K. J. Davies for expert technical assistance. 


\section{REFERENCES}

Bagg J 1982 Specific lectin-like interactions associated with bacterial attachment to host cells. PhD Thesis, University of Edinburgh, p 94.

Centeno A, Davis C P, Cohen M S, Warren M M 1983 Modulation of Candida albicans attachment to human epithelial cells by bacteria and carbohydrates. Infection and Immunity 39: 1354-1360.

Ellen R P, Fillery E D, Chan K H, Grove D A 1980 Sialidaseenhanced lectin-like mechanism for Actinomyces viscosus and Actinomyces naeslundii hemagglutination. Infection and Immunity 27:335-343.

Eshdat Y, Ofek I, Yashouv-Gan Y, Sharon N, Mirelman D 1978 Isolation of a manose-specific lectin from Escherichia coli and its role in the adherence of the bacteria to epithelial cells. Biochemical and Biophysical Research Communications 85: 1551-1559.

Gibbons R J, Nygaard M 1970 Interbacterial aggregation of plaque bacteria. Archives of Oral Biology 15:1397-1400.

Gibbons R J, van Houte J 1971 Selective bacterial adherence to oral epithelial surfaces and its role as an ecological determinant. Infection and Immunity 3:567-573.

Gibbons R J, van Houte J, Liljemark W F 1972 Parameters that affect the adherence of Streptococcus salivarius to oral epithelial surfaces. Journal of Dental Research 51:424-435.

Kelstrup J 1966 The incidence of Bacteroides melaninogenicus in human gingival sulci, and its prevalence in the oral cavity at different ages. Periodontics 4: 14-18.

Kolenbrander P E, Andersen R N, Holdeman L V 1985
Coaggregation of oral Bacteroides species with other bacteria: central role in coaggregation bridges and competitions. Infection and Immunity 48:741-746.

Lee J C, King R D 1983 Characterization of Candida albicans adherence to human vaginal epithelial cells in vitro. Infection and Immunity 41:1024-1030.

Liljemark W F, Bloomquist C G, Germaine G R 1981 Effect of bacterial aggregation on the adherence of oral streptococci to hydroxyapatite. Infection and Immunity 31:935-941.

Liljemark W F, Gibbons R J 1972 Proportional distribution and relative adherence of Streptococcus miteor (mitis) on various surfaces in the human oral cavity. Infection and Immunity $6: 852-859$.

Mirelman D, Altmann G, Eshdat Y 1980 Screening of bacterial isolates for mannose-specific lectin activity by agglutination of yeasts. Journal of Clinical Microbiology 11:328-331.

Mongiello J R, Falkler W A 1979 Sugar inhibition of oral Fusobacterium nucleatum haemagglutination and cell binding. Archives of Oral Biology 24:539-545.

Ofek I, Beachey E H 1980 Bacterial adherence. Advances in Internal Medicine 25:503-532.

Sandin R L, Rogers A L, Patterson R J, Beneke E S 1982 Evidence for mannose-mediated adherence of Candida albicans to human buccal cells in vitro. Infection and Immunity 35: 79-85.

Slots J, Gibbons R J 1978 Attachment of Bacteroides melaninogenicus subsp. asaccharolyticus to oral surfaces and its possible role in colonization of the mouth and of periodontal pockets. Infection and Immunity 19:254-264. 